\title{
NEOCUPROINE AND BATHOCUPROINE AS NEW REAGENTS FOR THE SPECTROPHOTOMETRIC DETERMINATION OF CERTAIN PROTON PUMP INHIBITORS
}

\author{
Akheel Ahmed Syed* and Ayesha Syeda \\ Department of Studies in Chemistry, University of Mysore, Mysore-570006, India
}

(Received September 13, 2006; revised April 17, 2007)

\begin{abstract}
Simple, sensitive and selective spectrophotometric methods were developed for the determination of five antiulcer drugs namely, omeprazole (OMZ), lansoprazole (LNZ), pantoprazole (PNZ), rabeprazole (RBZ) and esomeprazole (EMZ) using neocuproine or bathocuproine as reagents. The reaction is based on the reduction of copper(II) to copper(I) by OMZ, LNZ, PNZ, RBZ and EMZ which subsequently reacts with neocuproine or bathocuproine in neutral medium to produce yellow or orange-red coloured complex with maximum absorbance at 460 or $480 \mathrm{~nm}$, respectively. Beer's law was obeyed in the concentration range $0.2-4.0 \mu \mathrm{g} \mathrm{mL}^{-1}$ with a relative standard deviation ranging between 0.5-1.0 and 0.5-1.1 for the drugs with neocuproine and bathocuproine, respectively. The limits of detection were found to be $0.007-0.024$ and $0.01-0.026 \mu \mathrm{g} \mathrm{mL}^{-1}$ and the limits of quantification ranged between $0.019-0.067$ and $0.026-0.062 \mu \mathrm{g} \mathrm{mL} \mathrm{m}^{-1}$ with neocuproine and bathocuproine, respectively. The optimum assay conditions were investigated and the accuracy was found to be $99.3-100.5 \%$ and 99.1-100.7\%, while the correlation coefficients ranged between 0.9830-1.0213 and 0.9896-0.9981 with neocuproine and bathocuproine, respectively. The colour developed was stable for $24 \mathrm{~h}$ at room temperature $(\sim 27$ $\left.{ }^{\circ} \mathrm{C}\right)$. The commonly encountered excipients and additives did not interfere in the determination. Results obtained by this method for the pure drugs and commercial tablets agreed well with those obtained by reported method.
\end{abstract}

KEY WORDS: Neocuproine, Bathocuproine, Antiulcer drugs, Spectrophotometry

\section{INTRODUCTION}

Omeprazole (5-methoxy-2-[[(4-methoxy-3,5-dimethyl-2-pyridinyl)methyl]sulfinyl]-1H-benzimidazole), lansoprazole (2-[[[3-methyle-4-(2,2,2-trifluoroethoxy)-2-pyridinyl]methyl]sulfinyl]-1 $\mathrm{H}^{-}$ benzimidazole), pantoprazole (5-(difluoromethoxy)-2-[[3,4-dimethoxy-2-pyridinyl)methyl] sulfinyl]-1H-benzimidazole), rabeprazole (2-[[4-(3-methoxy propoxy)-3-methylpyridine-2-yl] methylsulfinyl]-1H-benzimidazole) and esomeprazole (bis [5-methoxy-2-[(S)-[(4-methoxy-3,5dimethyl-2-pyridinyl)methyl]sulfinyl]-1 $H$-benzimidizole) belong to the class of drugs referred to as proton pump inhibtors. They are substituted benzimidazoles, that suppress gastric acid secretion by specific inhibition of the $\mathrm{H}^{+} / \mathrm{K}^{+}$ATPase enzyme at the secretory surface of the gastric parietal cell [1]. Omeprazole is an important drug which is used alone or with other medications to decrease the amount of acid produced in the stomach and treat ulcers; gastroesophageal reflux disease, and erosive esophagitis. Omeprazole delayed-release capsules are also used in combination with other medications to eliminate $H$. pylori (a bacteria that causes ulcers) and possibly prevent new ulcers from developing in patients who have or have had ulcers of the small intestine. Thus, methods to quantify the drug(s) should be specific, precise and accurate.

Neocuproine and bathocuproine are the derivatives of 1,10-phenanthroline, which have gained prominence in analytical chemistry principally because of their importance as colouring reagents. They are widely used for the determination of small amounts of iron and copper. Several desirable features have been attributed to neocuproine and bathocuproine that make them ideally suitable for trace metal determination. The stability constants of metal chelates are

*Corresponding author. E-mail: akheelahmed54@rediffmail.com 
sufficiently great so that they form quantitatively even in the most dilute solutions provided a suitable $\mathrm{pH}$ and excess of reagents are employed. A wide range of methods has been proposed for the determination of antiulcer drugs which include: indirect argentometry [2], capillary electrophoresis [3], polarography [4-6], voltammetry [7, 8], flow injection analysis [9, 10], and high performance liquid chromatography [11-16].

Visible spectrophotometry appears to be the most appropriate analytical approach for the determination of antiulcer drugs, as it provides sensitive, precise and accurate measurements and offers practical and economical advantages over other methods. Besides, visible spectrophotometric detection is much more viable as a useful technique to develop a portable, on-line or at-line system.

This paper describes the work done to meet an ever-increasing demand for analytical control of these pharmaceuticals by developing simple and accurate spectrophotometric methods for the determination of omeprazole (OMZ), lansoprazole (LNZ), pantoprazole (PNZ), rabeprazole (RBZ) and esomeprazole (EMZ) in bulk and dosage forms. The procedures developed involve the reduction of copper(II) to copper(I) which subsequently reacts with neocuproine or bathocuproine in neutral medium to produce yellow or orange-red colour having maximum absorption at 460 or $480 \mathrm{~nm}$, respectively. The results show that neocuproine and bathocuproine can be used for the selective spectrophotometric determination of aforesaid proton pump inhibitors in the presence of copper(II) and the methods are simple and sensitive. Besides, the reagents offer clear advantages over most of the chromogenic reagents currently used for the purpose and the procedure shows positive features over existing methods.

\section{EXPERIMENTAL}

\section{Apparatus}

UV-VIS spectrophotometer UVIDEC-610 type with 1.0-cm matched cell (Jasco, Tokyo, Japan) was employed for measuring the absorbance.

\section{Reagents}

Omeprazole, lansoprazole, pantoprazole and rabeprazole from Cipla, India and commercial tablets of esomeprazole were used. Cupric sulfate (BDH, India), 2,9-dimethyl-1,10phenanthroline (neocuproine) (SRL, India) and 2,9-dimethyl-4,7diphenyl-1,10-phenanthroline (bathocuproine) (SRL, India) were used. All other chemicals and solvents were of analytical grade. Double distilled water was used throughout. Samples of the drugs each $100 \mathrm{mg}$ were dissolved in about $10.0 \mathrm{~mL}$ of ethanol made up to $100 \mathrm{~mL}$ mark using distilled water and stored in a refrigerator which were stable for three days. The stock solutions were diluted with distilled water to get solutions of required concentration. An aqueous solution of $0.001 \mathrm{M}$ copper(II) sulfate, $0.1 \%(\mathrm{w} / \mathrm{v})$ of neocuproine and $0.05 \%(\mathrm{w} / \mathrm{v})$ of bathocuproine were prepared in double distilled water and alcohol, respectively.

\section{Procedures}

Assay with copper(II) and neocuproine/bathocuproine. Aliquots of standard solutions of OMZ, LNZ, PNZ, RBZ and EMZ were transferred into $25-\mathrm{mL}$ calibrated flasks. To this $2.0 \mathrm{~mL}$ each of cupric sulfate and neocuproine or bathocuproine were added and the contents were shaken well. The flasks were kept in a boiling water bath for $10 \mathrm{~min}$ and cooled to room temperature. The 
solutions were made up to the volume with distilled water. The absorbance was measured at 460 and $480 \mathrm{~nm}$ with neocuproine and bathocuproine, respectively, against the corresponding reagent blank and calibration graph was constructed.

Job's method [17] of continuous variation was employed for the determination of the molar ratio of OMZ-copper(II) reaction with neocuproine and bathocuproine as an example. Aqueous solutions of OMZ (100 mg/L), copper(II) $\left(1 \times 10^{-3} \mathrm{M}\right)$ and neocuproine or bathocuproine $(1 \mathrm{x}$ $10^{-3} \mathrm{M}$ ) were used. A series of standard solutions of $\mathrm{OMZ}$ and neocuproine or bathocuproinecopper(II) in different complimentary proportions were prepared and the absorbance was measured at 460 or $480 \mathrm{~nm}$ against blanks prepared under the same conditions.

\section{Pharmaceutical preparations}

Twenty tablets of each antiulcer drug (pantoprazole, rabeprazole and esomeprazole) were finely powdered in a small dish. In case of capsules (omeprazole and lansoprazole) the contents were emptied carefully and the mass of the collected contents was determined. The capsule contents were finely powdered in a mortar. Fifty $\mathrm{mg}$ of this powder was dissolved in about $10 \mathrm{~mL}$ of ethanol and filtered through a Whatman No. 42 filter paper. The filtrate was made up to mark with distilled water in a $100-\mathrm{mL}$ volumetric flask. A suitable volume of the filtrate was accurately diluted with water to get a sample concentration of $10 \mu \mathrm{g} \mathrm{mL}^{-1}$. An aliquot of this solution was used for the determination of each antiulcer drug as per the procedures described earlier.

\section{RESULTS AND DISCUSSION}

\section{Spectral characteristics}

A yellow or orange-red coloured product with maximum absorbance at 460 or $480 \mathrm{~nm}$, in the presence of neocuproine or bathocuproine, respectively was formed when OMZ was allowed to react with cupric sulfate, in neutral medium. Neutral medium was chosen as the compounds under study are acid labile and are reversibly transformed in acidic medium to a sulfonamide [18]. The spectral characteristics are presented in Table 1 and 2.

Table 1. Optical characteristics of the chromogen of antiulcer drugs using neocuproine.

\begin{tabular}{|l|c|c|c|c|c|}
\hline Parameters & OMZ & LNZ & PNZ & RBZ & EMZ \\
\hline Colour & Yellow & Yellow & Yellow & Yellow & Yellow \\
\hline$\lambda_{\max }(\mathrm{nm})$ & 460 & 460 & 460 & 460 & 460 \\
\hline Stability $(\mathrm{h})$ & 24 & 24 & 24 & 24 & 24 \\
\hline Beer's law $\left(\mu \mathrm{g} \mathrm{mL}^{-1}\right)$ & $0.08-2.8$ & $0.2-3.6$ & $0.2-4.8$ & $0.2-3.4$ & $0.2-2.8$ \\
\hline $\begin{array}{l}\text { Recommended drug } \\
\text { concentration }\left(\mu \mathrm{g} \mathrm{mL} \mathrm{m}^{-1}\right)\end{array}$ & 1.2 & 1.6 & 2.4 & 1.8 & 1.4 \\
\hline $\begin{array}{l}\text { Molar absorptivity } \\
\left(\mathrm{L} \mathrm{mol}^{-1} \mathrm{~cm}^{-1}\right)\end{array}$ & $7.08 \times 10^{4}$ & $5.82 \times 10^{4}$ & $5.55 \times 10^{4}$ & $5.20 \times 10^{4}$ & $6.15 \times 10^{4}$ \\
\hline $\begin{array}{l}\text { Sandell's sensitivity } \\
\left(\mu \mathrm{gm}^{-2}\right)\end{array}$ & 0.005 & 0.006 & 0.007 & 0.007 & 0.006 \\
\hline Correlation coefficient & 0.9954 & 1.0213 & 0.9850 & 0.9980 & 0.9830 \\
\hline RSD $(\mathrm{n}=5)$ & \pm 0.9 & \pm 0.5 & \pm 0.7 & \pm 0.6 & \pm 1.0 \\
\hline Accuracy \% & 99.8 & 100.1 & 99.3 & 100.5 & 100.2 \\
\hline LOD $\mu \mathrm{g} \mathrm{mL}$ & 0.007 & 0.017 & 0.021 & 0.024 & 0.014 \\
\hline LOQ $\mu \mathrm{g} \mathrm{mL} \mathrm{mL}^{-1}$ & 0.019 & 0.067 & 0.058 & 0.044 & 0.053 \\
\hline
\end{tabular}

OMZ: Omeprazole, LNZ: Lansoprazole, PNZ: Pantoprazole, RBZ: Rabeprazole, EMZ: Esomeprazole. 
Table 2. Optical characteristics of the chromogen of antiulcer drugs using bathocuproine.

\begin{tabular}{|l|c|c|c|c|c|}
\hline Parameters & OMZ & LNZ & PNZ & RBZ & EMZ \\
\hline Colour & Orange-red & Orange-red & Orange-red & Orange-red & Orange-red \\
\hline$\lambda_{\max }(\mathrm{nm})$ & 480 & 480 & 480 & 480 & 480 \\
\hline Stability $(\mathrm{h})$ & 24 & 24 & 24 & 24 & 24 \\
\hline Beer's law $\left(\mu \mathrm{g} \mathrm{mL}^{-1}\right)$ & $0.08-2.6$ & $0.2-3.2$ & $0.2-4.0$ & $0.2-3.2$ & $0.2-2.8$ \\
\hline $\begin{array}{l}\text { Recommended drug } \\
\text { concentration }\left(\mu \mathrm{g} \mathrm{mL} \mathrm{m}^{-1}\right)\end{array}$ & 1.0 & 1.4 & 2.0 & 1.6 & 1.2 \\
\hline Molar absorptivity $\left(\mathrm{L} \mathrm{mol}^{-1} \mathrm{~cm}^{-1}\right)$ & $9.12 \times 10^{4}$ & $7.17 \times 10^{4}$ & $7.16 \times 10^{4}$ & $7.09 \times 10^{4}$ & $7.65 \times 10^{4}$ \\
\hline Sandell's sensitivity $\left(\mu \mathrm{g} \mathrm{cm}^{-2}\right)$ & 0.004 & 0.005 & 0.005 & 0.005 & 0.005 \\
\hline Correlation coefficient & 0.9938 & 0.9957 & 0.9896 & 0.9899 & 0.9981 \\
\hline RSD $(\mathrm{n}=5)$ & \pm 0.5 & \pm 0.7 & \pm 0.6 & \pm 0.9 & \pm 1.1 \\
\hline Accuracy \% & 100.3 & 99.7 & 99.1 & 100.7 & 99.6 \\
\hline LOD $\mu \mathrm{g} \mathrm{mL}$ & 0.010 & 0.013 & 0.011 & 0.022 & 0.026 \\
\hline LOQ $\mu \mathrm{g} \mathrm{mL}$ & 0.026 & 0.047 & 0.056 & 0.036 & 0.062 \\
\hline
\end{tabular}

OMZ: Omeprazole, LNZ: Lansoprazole, PNZ: Pantoprazole RBZ: Rabeprazole, EMZ: Esomeprazole.

\section{Optimization of analytical variables}

Maximum and constant absorbance values were obtained when the standard flasks were kept in a boiling water bath for $10 \mathrm{~min}$ after adding the reagents to the drug solutions. The development of colour in acids such as hydrochloric acid, sulphuric acid, acetic acid, nitric acid, phosphoric acid and formic acid was slow.

It was found that $0.001 \mathrm{M}$ cupric sulfate solution in the range of $1.0-3.0 \mathrm{~mL}$ and $0.1 \%(\mathrm{w} / \mathrm{v})$ of neocuproine in the range of $1.5-4.0 \mathrm{~mL}$ or $0.05 \%(\mathrm{w} / \mathrm{v})$ of bathocuproine in the range of 1.0$3.0 \mathrm{~mL}$ provided maximum colour intensity and stability. Hence, $2.0 \mathrm{~mL}$ each of cupric sulfate and neocuproine or bathocuproine solution were found optimum.

The sequence of addition of cupric sulfate, neocuproine or bathocuproine and drug solution was studied via the formation of the yellow or orange-red complex. There was no appreciable change in the absorbance or the intensity of the colour of the product when the sequence of these reactants was altered.

The development of the colour was slow at room temperature. The absorbance values were maximum and remained constant in the temperature range $80-100{ }^{\circ} \mathrm{C}$. However, after cooling to ambient temperature the products remained stable for $24 \mathrm{~h}$.

The factors affecting the colour development such as reproducibility, sensitivity and adherence to Beer's law were investigated using omeprazole as a model representative compound, since the reaction of other antiulcer drugs was similar.

In the complexation reaction, the metal gets reduced by the drug and subsequently forms complex with the reagent. Investigations of the continuous molar variation of OMZ-copper(II) and neocuproine or bathocuproine showed that the copper(I) interacts with neocuproine or bathocuproine in 1:2 ratio. Similar results have been observed with the mole-ratio method.

\section{Interference}

The interference by various substances that often accompany antiulcer drugs in pharmaceutical preparations was studied by taking omeprazole as a representative drug. It was found that, commonly encountered pharmaceutical additives and excipients such as glucose, lactose, dextrose, starch, sodium alginate and sodium lauyrl sulphate did not interfere in the determination, while vitamin $\mathrm{C}$ was found to seriously interfere (Table 3). The commercially available formulation in Indian market for the drugs studied invariably contains red oxide of iron, yellow oxide of iron and titanium dioxide which did not interfere with the determination. 
Though the formulations containing proton pump inhibitors and vitamin $\mathrm{C}$ are not commercially available, yet many patients will have an additional supplement of vitamin C. Hence preliminary investigations were carried out to study in vivo interferences from substances present in pathological urine samples. For in vivo test each of three volunteers who are healthy persons were given a tablet each of omeprazole for three days. Their urines were tested using the proposed spectrophotometric methods. The same volunteers were given $1 \mathrm{~g}$ of vitamin $\mathrm{C}$ and 20 $\mathrm{mg}$ of omeprazole per person for three days and their urines were tested. In the first set of trails reproducible values with $\mathrm{RSD}$ of $\pm 0.7, \pm 1.1$ and \pm 0.9 were obtained. However, with the later set of trails the results were erratic and displayed poor reproducibility.

Table 3. Recovery of omeprazole (OMZ) in the presence of excipients and other substances.

\begin{tabular}{|l|c|c|c|}
\hline \multirow{2}{*}{ Material } & \multirow{2}{*}{$\begin{array}{c}\text { Amount } \\
(\mathrm{mg})\end{array}$} & \multicolumn{2}{|c|}{ Recovery of OMZ* \pm RSD $(\mathrm{n}=5)$} \\
\cline { 3 - 4 } & 50 & Neocup. & Bathocup. \\
\hline Glucose & 50 & $100.2 \pm 0.8$ & $100.8 \pm 0.6$ \\
\hline Lactose & 50 & $98.8 \pm 0.9$ & $98.6 \pm 1.1$ \\
\hline Dextrose & 50 & $99.2 \pm 0.7$ & $99.2 \pm 0.7$ \\
\hline Magnesium stearate & 50 & $101.4 \pm 1.1$ & $101.2 \pm 0.9$ \\
\hline Starch & 50 & $98.2 \pm 0.8$ & $100.8 \pm 0.8$ \\
\hline Gum acacia & 50 & $99.6 \pm 1.0$ & $99.2 \pm 0.6$ \\
\hline Talc & 50 & $98.6 \pm 0.6$ & $98.6 \pm 1.1$ \\
\hline Vitamin B $_{6}$ & 50 & $101.8 \pm 0.9$ & $101.4 \pm 0.8$ \\
\hline Carboxyl methyl cellulose & 50 & $99.0 \pm 0.8$ & $100.8 \pm 1.0$ \\
\hline Sodium alginate & 10 & ${ }^{\#}>50<60$ & ${ }^{\#}>50<60$ \\
\hline Vitamin C & &
\end{tabular}

*1.0 $\mu \mathrm{g} \mathrm{mL}^{-1}$ of OMZ taken. "Erratic values.

\section{Analysis of pharmaceutical formulations}

The applicability of the method to assay pharmaceutical preparations was examined. Commercial capsules/tablets containing omeprazole, lansoprazole, pantoprazole, rabeprazole and esomeprazole were analyzed by the proposed new method. The results obtained are presented in Table 4 and 5. Statistical tests (F- and $\mathrm{t}-$ ) were applied to the results and no difference was found between the calculated and theoretical values.

Table 4. Determination of certain antiulcer drugs in commercial samples by the proposed method using neocuproine.

\begin{tabular}{|l|c|l|c|l|l|}
\hline Drug & $\begin{array}{l}\text { Label claim } \\
(\mathrm{mg} / \mathrm{drug})\end{array}$ & $\begin{array}{l}\text { Proposed method } \\
\text { Recovery } \% \pm \mathrm{SD}\end{array}$ & $\begin{array}{c}\text { Analyte } \\
\text { added }(\mathrm{mg})\end{array}$ & $\begin{array}{l}\text { Proposed method } \\
\text { Recovery\% } \pm \mathrm{SD}\end{array}$ & $\begin{array}{l}\text { Reported method } \\
\text { found \% }\end{array}$ \\
\hline $\begin{array}{l}\text { Omelac capsule } \\
\text { (Omeprazole) }\end{array}$ & 20 & $\begin{array}{l}98.0 \pm 0.5 \\
\mathrm{~F}=4.07(6.39) \\
\mathrm{t}=1.46(2.77)(\mathrm{n}=5)\end{array}$ & 20 & $99.2 \pm 0.9(\mathrm{n}=5)$ & $\begin{array}{l}97.2 \pm 1.1[19] \\
(\mathrm{n}=5)\end{array}$ \\
\hline $\begin{array}{l}\text { Lanpro capsule } \\
\text { (Lansoprazole) }\end{array}$ & 15 & $\begin{array}{l}99.5 \pm 0.2 \\
\mathrm{~F}=2.12(6.39) \\
\mathrm{t}=1.44(2.77)(\mathrm{n}=5)\end{array}$ & 15 & $100.2 \pm 0.6(\mathrm{n}=5)$ & $\begin{array}{l}99.6 \pm 0.1[20] \\
(\mathrm{n}=5)\end{array}$ \\
\hline $\begin{array}{l}\text { Pan tablet } \\
\text { (Pantoprazole) }\end{array}$ & 20 & $\begin{array}{l}97.6 \pm 0.7 \\
\mathrm{~F}=1.39(9.28) \\
\mathrm{t}=1.77(3.18)(\mathrm{n}=4)\end{array}$ & 20 & $99.6 \pm 1.1(\mathrm{n}=4)$ & $\begin{array}{l}98.5 \pm 0.6[19] \\
(\mathrm{n}=4)\end{array}$ \\
\hline $\begin{array}{l}\text { Rabeloc tablet } \\
\text { (Rabeprazole) }\end{array}$ & 20 & $\begin{array}{l}99.0 \pm 0.6 \\
\mathrm{~F}=1.99(4.28) \\
\mathrm{t}=2.03(2.44)(\mathrm{n}=7)\end{array}$ & 20 & $101.4 \pm 0.6(\mathrm{n}=7)$ & $\begin{array}{l}98.4 \pm 0.4 \\
{[21](\mathrm{n}=7)}\end{array}$ \\
\hline $\begin{array}{l}\text { Raciper tablet } \\
\text { (Esomeprazole) }\end{array}$ & 20 & \begin{tabular}{l}
$100.4 \pm 1.1(\mathrm{n}=5)$ \\
\hline
\end{tabular}
\end{tabular}

The figures in parentheses are the tabulated F- and t- values at $95 \%$ confidence level. 
Table 5. Determination of certain antiulcer drugs in commercial samples by the proposed method using bathocuproine.

\begin{tabular}{|l|c|c|c|c|c|}
\hline Drug & $\begin{array}{c}\text { Label claim } \\
(\mathrm{mg} / \mathrm{drug})\end{array}$ & $\begin{array}{c}\text { Proposed method } \\
\text { Recovery } \% \pm \mathrm{SD}\end{array}$ & $\begin{array}{c}\text { Analyte } \\
\text { added }(\mathrm{mg})\end{array}$ & $\begin{array}{c}\text { Proposed method } \\
\text { Recovery\% } \pm \text { SD }\end{array}$ & $\begin{array}{c}\text { Reported method } \\
\text { found \% }\end{array}$ \\
\hline $\begin{array}{l}\text { Omelac capsule } \\
\text { (Omeprazole) }\end{array}$ & 20 & $\begin{array}{c}98.4 \pm 0.7 \\
\mathrm{~F}=2.57(6.39)\end{array}$ & 20 & $\begin{array}{c}100.2 \pm 0.5 \\
(\mathrm{n}=5)\end{array}$ & $\begin{array}{c}97.2 \pm 1.1[19] \\
(\mathrm{n}=5)\end{array}$ \\
\hline $\begin{array}{l}\text { Lanpro capsule } \\
\text { Lansoprazole) }\end{array}$ & 15 & $\begin{array}{c}99.8 \pm 0.2 \\
\mathrm{~F}=3.31(6.39) \\
\mathrm{t}=1.64(2.77)(\mathrm{n}=5)\end{array}$ & 15 & $\begin{array}{c}99.8 \pm 0.6 \\
(\mathrm{n}=5)\end{array}$ & $\begin{array}{c}99.6 \pm 0.1[20] \\
(\mathrm{n}=5)\end{array}$ \\
\hline $\begin{array}{l}\text { Pan tablet } \\
\text { Pantoprazole) }\end{array}$ & 20 & $\begin{array}{c}97.6 \pm 0.7 \\
\mathrm{~F}=1.39(9.28) \\
\mathrm{t}=1.77(3.18)(\mathrm{n}=4)\end{array}$ & 20 & $\begin{array}{c}100.6 \pm 0.7 \\
(\mathrm{n}=4)\end{array}$ & $\begin{array}{c}98.5 \pm 0.6[19] \\
(\mathrm{n}=4)\end{array}$ \\
\hline $\begin{array}{l}\text { Rabeloc tablet } \\
\text { (Rabeprazole) }\end{array}$ & 20 & $\begin{array}{c}98.8 \pm 0.6 \\
\mathrm{~F}=3.24(4.28)\end{array}$ & 20 & $\begin{array}{c}99.4 \pm 0.9 \\
(\mathrm{n}=7)\end{array}$ & $\begin{array}{c}98.4 \pm 0.4[21] \\
(\mathrm{n}=7)\end{array}$ \\
\hline $\begin{array}{l}\text { Raciper tablet } \\
\text { (Esomeprazole) }\end{array}$ & 20 & $\begin{array}{c}\mathrm{t}=1.41(2.44)(\mathrm{n}=7) \\
99.6 \pm 0.8(\mathrm{n}=5)\end{array}$ & 20 & $\begin{array}{c}99.2 \pm 0.7 \\
(\mathrm{n}=5)\end{array}$ & - \\
\hline
\end{tabular}

The figures in parentheses are the tabulated F- and t- values at $95 \%$ confidence level.

United States Pharmacopeia, European Pharmacopeia, British Pharmacopeia and Indian Pharmacopeia do not give any titrimetric or spectrophotometric method as a reference. While, only chromatographic methods have been recommended. In the absence of chromatographic methods we have adopted standard addition method to validate our proposed methods.

The details of existing spectrophotometric reagents and their spectral characteristics are enumerated in Table 6.

Table 6. Comparison of visible spectrophotometric methods for the determination of antiulcer drugs.

\begin{tabular}{|c|c|c|c|c|c|}
\hline Reagent & Solvent & Drugs analyzed & $\lambda_{\max } \mathrm{nm}$ & $\begin{array}{c}\text { Range of } \\
\text { determination } \\
\mu \mathrm{g} \mathrm{mL}^{-1} \\
\end{array}$ & Ref. \\
\hline \multicolumn{6}{|l|}{ Aqueous media } \\
\hline Eosin and copper(II) & - & LNZ, PNZ & 549 & $3.69-16.61,4.3-25.9$ & {$[20]$} \\
\hline MBTH & - & $\mathrm{OMZ}$ & 660 & $1.0-10.0$ & {$[22]$} \\
\hline$m$-Aminophenol & - & OMZ & 420 & $2.0-32$ & {$[22]$} \\
\hline Proposed method & - & $\begin{array}{c}\text { OMZ, LNZ, } \\
\text { PNZ, RBZ, EMZ }\end{array}$ & 460,480 & $0.2-4.0$ & - \\
\hline \multicolumn{6}{|l|}{ Non-aqueous media } \\
\hline Iron(III) & Ethanol & PNZ & 455 & $30-300$ & [19] \\
\hline Iron(III) & Ethanol & OMZ & 411 & $15-95$ & [19] \\
\hline Chromium(III) & Ethanol & OMZ & 339 & $10-60$ & [19] \\
\hline Cobalt(II) & Ethanol & OMZ & 523 & $15-150$ & [19] \\
\hline $\begin{array}{l}\text { 2,3-Dichloro-5,6- } \\
\text { dicyano-1,4- } \\
\text { benzoquinone }\end{array}$ & Acetonitrile & LNZ, PNZ & 457 & $10-90,10-60$ & {$[20]$} \\
\hline Iodine & Chloroform & LNZ, PNZ & 293,359 & $1.48-6.65,17.7-141.6$ & [20] \\
\hline
\end{tabular}

OMZ: Omeprazole, LNZ: Lansoprazole, PNZ: Pantoprazole, RBZ: Rabeprazole, EMZ: Esomeprazole. 


\section{CONCLUSIONS}

The present trend in pharmaceutical analysis is in the direction of further improvement of physico-chemical methods of analysis of pharmaceutical preparations. The development of simple methods for analyzing the complex medicinal mixtures is one of the thrust areas of pharmaceutical analyses. Neocuproine and bathocuproine are very useful as a new class of spectrophotometric reagents for the determination of OMZ, LNZ, PNZ, RBZ and EMZ as they exhibit better sensitivity and higher reproducibility. The use of aqueous neutral medium and easily available chemicals make the procedures cost-effective and adaptable. The procedures described herein meet most of the demands of analytical chemists namely selectivity, simplicity, reliability and cost of analysis. Thus, it can be concluded that spectrophotometric methods are more versatile and easy to apply than other instrumental methods.

\section{AKNOWLEDGEMENTS}

The authors are grateful to Cipla, India for gift sample of OMZ, LNZ, PNZ and RBZ. One of the authors (AS) thanks University of Mysore, India for granting permission to carry out research work.

\section{REFERENCES}

1. Morii, M.; Takata, H.; Fujisaki, H. Biochem. Pharmacol. 1990, 39, 661.

2. Zhang, A.H.; Wang, F.; Chen, X.J.; Wu, L.K. Yaowu Fenxi Zazhi 1996, 16, 194.

3. Eberle, D.; Hummel, R.P.; Kuhn, R. J. Chromatogr. A 1997, 759, 185.

4. Oelschlaeger, H.; Knoth, H. Pharmazie 1998, 53, 242.

5. Dogrukol-Ak, D.; Tuncel, M. Pharmazie 1995, 50, 701.

6. Ozaltin, N.; Temizer, A. Electroanal. 1994, 6, 799.

7. Radi, A.; Abd El-ghany, N.; Wahdan, T. Il Farmaco 2004, 59, 515.

8. Pinzauti, S.; Gratteri, P.; Furianetto, S.; Mura, P.; Dreassi, E.; Phan-Tan-Luu, R. J. Pharm. Biomed. Anal. 1996, 14, 881.

9. Tuncel, M.; Dogrukol-Ak, D. Pharmazie 1997, 52, 73.

10. Yeniceli, D.; Dogrukol-Ak, D.; Tuncel, M. J. Pharm. Biomed. Anal. 2004, 36, 145.

11. Cass, Q.B.; Degani, A.L.G.; Cassiano, N.M.; Pedrazolli J. Jr. J. Chromatogr. B 2001, 766, 153.

12. Katsuki, H.; Hamada, A.; Nakamura, C.; Arimori, K.; Nakano, M. J. Chromatogr. B 2001, $757,127$.

13. Macek, J.; Ptacek, P.; Klima, J. J. Chromatogr. B 1997, 689, 239.

14. Karol, M.D.; Granneman, G.R.; Alexander, K. J. Chromatogr. B 1995, 668, 182.

15. Andersson, T.; Pre-Olof, L.; Miners, J.O.; Veronese, M.E.; Weidolf, L.; Birkett, D.J. J. Chromotogr. 1993, 619, 291.

16. Delhotal Lades, B.; Miscoria, G.; Flouvat, B. J. Chromatogr. 1992, 577, 117.

17. Rose, J. Advanced Physico-Chemical Experiments, Pitman: London; 1964; p 54.

18. McClean, S.; O’Kane, E.; Ramachandran, V.N.; Smyth, W.F. Anal. Chim. Acta 1994, 292, 81.

19. Salama, F.; El-Abasawy, N.; Abdel Razeq, S.S.; Ismail, M.M.F.; Fouad, M.M. J. Pharm. Biomed. Anal. 2003, 33, 411.

20. Moustafa, A.A.M. J. Pharm. Biomed. Anal. 2000, 22, 45.

21. El-Gindy, A.; El-Yazby, F.; Maher, M.M. J. Pharm. Biomed. Anal. 2003, 31, 229.

22. Sastry, C.S.P.; Naidu, P.Y.; Murty, S.S.N. Talanta 1997, 44, 1211. 